\title{
GALILEO’s RHETORIC OF FABLE
}

\section{Crystal Hall}

Summary: In annotations, drafts, and published materials, Galileo Galilei (1564-1642) consistently uses fables to ridicule his philosophical opponents' forma mentis. An analysis of the revisions made to these short pieces argues that the fable was a deliberate rhetorical tool with dual effect: the ability to undercut the validity of intellectual approaches and the appeal to a broader audience. Galileo draws on the traditions of vernacular satire and Latin exempla to provide a subtle manual for how to think, read, and write in the new scientific climate that his work had generated. Contextualized against the more-widely read "Fable of the Researcher of Sounds" from the Assayer (1623), these negatively characterized exempla demonstrate what this article calls a "rhetoric of fable."

One of Aesop's fables frequently repeated in collections of motti, facezie, and burle of the Quattrocento and Cinquecento literally demonstrates the pitfalls that await astronomers when they wander into the territory of fable:

Giva per l'ombre dell'oscura notte

Del Cielo a contemplar le Stelle

Un dottissimo Astrologo e interrotte

Le vie li fur da sorte iniquie \& felle,

Ch'a quelle inteso, a lui le gambe rotte

Rimasero in un pozzo, ove con elle

Intere cadde: un disse à lui: Tu vedi

Lì il Ciel si lunge, e non quel'ch'hai tra i piedi? 1

The moral of the tale reads: "Se non vedete quel' che v'è da presso, come vedrete quel' che v'è lontano?" Astronomers, philosophers, and other intellectual elite rarely find happy endings in the short stories, fables, and facezie (witticisms) of the late Renaissance. To modern sensibilities, one category necessarily excludes the other: astronomy has no business with fable, and fable has little interest in scientific method. Yet, Leonardo da Vinci wrote a collection of fables that illustrate the dangers of ignorance of nature, and Giordano Bruno's tale of the lion and the ass memorably punc-

1 Targa, Cento e cinquanta favole, 85. 
tuates the Candelaio (1582). Galileo Galilei (1564-1642) owned several classical philosophical treatises that have frequent recourse to anecdotes, exempla, fables, and fictional short stories, such as Pliny's Natural History and Plutarch's Moralia. ${ }^{2}$ So then, is the fact that Galileo owned several of the most popular late-Renaissance collections of fictional tales and historical exempla simply a sign of his identity as a man of letters? Are the fables he writes in line with philosophical tradition? An examination of the materials in Galileo's library alongside his use and criticism of fables brings to light a new relationship between philosophy and fable, one that recycles forms of fiction as part of a rhetorical strategy to elaborate the new scientific method.

Central to this analysis is a series of thirteen vignettes, or synthesized fables, that are all found within Galileo's responses to his detractors and authors he criticizes, among whom are the poet Torquato Tasso and the Jesuit philosopher, Horatio Grassi. Some of these fables and facezie can be found in the margins of works by other authors, that is, in a form that was meant to be private, but Galileo also used his marginalia as draft material for published works. The fables are unanalyzed evidence of what Jean Dietz Moss has called in other contexts the "grace" with which Galileo rhetorically "destroys" his opponents. ${ }^{3}$ The protagonists of these stories are stock characters from collections of witticisms, exempla, and short stories. In the context of satire and digressions, Andrea Battistini has referred to some of the characters in these short stories as "figurine protagoniste di aneddoti mai meramente descrittivi, ma esposti a intenti stranianti." 4 More than satirical annecdotes or weapons of ethos destruction, these tales are a collage of Jolles' pre-literary "simple forms": legend, myth, enigmas, aphorisms, exempla, memorabilia, fables, and witticisms. ${ }^{5}$ By using a selection of materials from this group, primarily the fable and the exemplum, Galileo can speak to a moment of pre-comprehension that lays bare the fault of his opponent and makes an ally of the reader in his act of judgment. The exemplum is both a moment of dialogue between the author and reader that demonstrates the validity of the argument being made, as well as a call to action either to imitate or avoid such action. ${ }^{6}$ Dialogue and action subvert

2 For all references to Galileo's library, readers should see Favaro, Libreria di Galileo.

3 Novelties in the Heavens, 276.

4 Galileo e i Gesuiti, 157.

5 Barillari, Motti, arguzie, facezie, 1.

6 Bremond, Le Goff, and Schmitt, L'Exemplum, 8; and Delcorno, Exemplum e letteratura, 11. 
the classical monologue of Aristotelian philosophy, a voice of authority that over the centuries passed from edition to revised edition without the renewed investigation that Galileo so ardently championed. The resulting collection of Galileo's short stories reads like an etiquette manual for how to think, read, and write, expressed via examples of bad behavior.

These brief narrative interludes defy easy categorization because of the various lables for the genre. For example, Galileo will call one opponent a lying lawyer, an inappropriate dancer, a poor bluffer at cards, and a snobby cloth buyer. False testimony, dancing, gambling, and "pompose vesti" happen to be the topics of chapters VII, X, XI, and XII in a popular collection of exempla for use in sermons of the period.7 Nonetheless, Galileo's examples and the catalog of exempla share only a topic and mutual condemnation in common, not content or moralizing structure. Moreover, in the early seventeenth century the distinction between favola and fiaba had not been made, so favola here can refer to Aesop's Fabulae as well as to Boccaccio's Decameron, and accordingly to Galileo's fictional stories. ${ }^{8}$ Beyond this, the stories are often expressed with the rapidity of an anecdote, but without markers of time, place, or person.

Further still, their use resembles that of the facezia, the witticism, which provokes a laugh at the expense of the protagonist who is here, by analogy, Galileo's opponent. These clever remarks were a valued part of court discussions, described as early as Stefano Guazzo's Civile conversazione (Brescia, 1574). Often categorized with motti, burle, and arguzie, these various witticisms were popularized by the Italian humanist Poggio Bracciolini (1380-1459) and the Padovan humorist Arlotto Mainardi (1396-1484), and later compiled and circulated by Lodovico Domenichi (1515-1564). Galileo owned a copy of one of Domenichi's collections of humorous tales, clever stories, and witty retorts, which saw several editions in the sixteenth century under various titles. Building on the Ciceronian tradition that "a jocose manner... and stroke of wit, give pleasure to an audience, and are often of great advantage to the speaker," the Florentines in particular added elements of satire, derision, and cyncism to these exemplary tales. ${ }^{9}$ His contemporaries were well aware of the freedoms that this form allowed. In a letter to Galileo from June 24, 1607, Lodovico delle Colombe defends language that Galileo could have interpreted as inflam-

\footnotetext{
7 Valerio da Venezia, Prato fiorito, pp. 35, 49, 54, 58. First edition Venice, 1610.

8 Vocabolario degli Accademici della Crusca, 335-36.

9 Cicero, On Oratory and Orators, 144. For the reference to Florentine tradition, see Bracciolini, Facetiae, 2-6.
} 
matory or derisive by saying "non ho passato i termini dell'huomo da bene, quantunque, secondo l'occasion datami, habbia ribattuto le morsicature, perchè l'ho fatto con piacevolezze e motti e facezie, senza animosità veruna." (X, 177) ${ }^{10}$ The witticism would then appear to be a neutral zone of poking fun at an individual that permits a critique of the condition of the intellectual even before a debate on the correct interpretation of data need begin, but without transmitting a formal offense to its object. The use of such a hybrid, or even contaminated, smart remark, referred to here under the generic label of "fable" or exemplum, dovetails the relationships of the author with classical tradition, his reader, the text he criticizes, and his presentation of a new method of intellectual inquiry. Accordingly, this paper evaluates the models of fables and exempla at Galileo's disposal in his library and how he incorporates or rejects their contents in his subsequent writing.

An early example of this rhetoric demonstrates both the deliberate use of these abbreviated fables in Galileo's published works as well as their role in defining his new method of philosophizing. In late 1612 and early 1613, Galileo was involved in a debate on the nature of sunspots with a Jesuit mathematician, Christoph Scheiner, who was writing under a pseudonym, Apelles. Scheiner wrote two series of letters answered by three letters from Galileo, all written to a common friend who published the entire exchange in Rome in 1613. Near the end of the Third Letter on the Sunspots, in a discussion on the impossibility of reconciling repeated and diligent observations with an erroneous theory, Galileo introduces an emblematic figure: a castle keeper under siege. The example takes on a particularly sarcastic tone if one considers that Galileo had previously written an entire treatise on castle fortifications. (II, 79-146) Prior to composing the Third Letter, Galileo had written a note in his copy of Scheiner's second letter to Welser:

Peripatetici simili a i deboli difensori di una fortezza, li quali, vedendola assalir da una banda, accorrono tutti là, non curando intanto di lasciar senza difesa gli altri luoghi, a i quali l'inimico più numeroso si volta, vedendogli sprovvisti. Ora i Peripatetici, per soccorrer all'imminente pericolo della alterabilità del cielo, corrono alla difesa con dir le macchie essere stelle; e intanto lasciano mill'altri aditi aperti agli assalti inimici, perchè non più vien salvato il numero settenario de i pianeti, non la lor conversione intorno alla Terra, non la regolarità de i lor movimenti, etc. (V, 232 n. 1)

10 All parenthetical references are to Galileo's collected Opere. 
The fortress of the Peripatetics, a recurring image in Galileo's later works, has a number of structural weaknesses. To defend one philosophical tenet, they undermine the strength of others. By saying that sunspots are stars, they can defend the inalterability of the skies, but they can no longer defend certain other statements about stars and planets.

In the final version of the Third Letter, while talking about the broader argument, the immutability of the skies, Galileo revises his earlier description of the Peripatetics' faulty defence strategy by presenting a mild warning against losing the forest for the trees:

per non far come quel castellano che, sendo con piccol numero di soldati alla difesa d'una fortezza, per soccorrer quella parte che vede assalita vi accorre con tutte le forze, lasciando intanto altri luoghi indifesi ed aperti, conviene che, mentre ci sforziamo di difender l'immutabilità del cielo, non ci scordiamo de i pericoli a i quali per avventura potriano restar esposte altre proposizioni, pur necessarie alla conservazione della filosofia peripatetica. $(\mathrm{V}, 232)$

In this published piece, the "deboli difensori" are changed into a singular, unmodified castellan of a fortress that is passively "assalita" without mention of the "banda" or "inimico" of the original marginal note. The critique of carelessness in the annotation has been replaced with a tone of sympathy in the publication. Rather than maintaining the sense of otherness, Galileo opts for the inclusive "we," proposing a collective effort to remember and consider the repercussions of making broad statements. As a foolish or inept figure whose identity changes between the private and public version of the story, the castellan exemplifies Galileo's use of the fable as a rhetorical device. In more cases than not, the shift from marginalia to published document involves a mutation of the style and tone of these vignettes, yet the general point remains consistent. The tale judges the procedure of intellectual inquiry. Unlike the fables used in antiquity to unlock a mystery of the book of nature, here the goal is to reveal human nature.

Galileo frequently uses this rhetorical strategy of fable and exemplum, but he first specifically voices an anti-fable position in the text in which he employs them most often, the Saggiatore, or Assayer (Rome, 1623). This work is the middle text in a series of publications written primarily by Galileo and the Jesuit scholar Horatio Grassi. Now known as the "Controversy on the Comets of 1618," the exchange began with a small treatise on the comets published by the Jesuits, followed by a counter-argument printed under the name of Galileo's student, Mario Guiducci, but 
written in great part by the master himself. (VI, 5-19) The professor-pupil rebuke provoked immediate response from Grassi, who assumed the identity of his own fictitious student, Lothario Sarsi, to publish the Libra astronomica ac philosophica, or Astronomical and Physical Balance (Perugia, 1619) in which he "weighs" each of Galileo-Guiducci's arguments. Guiducci replied immediately and Galileo responded four years later with a line-by-line critique of Grassi's Balance. To demonstrate to readers the faults he saw in Sarsi's methods, Galileo reproduced the work in its entirety within the body of the Assayer, interspersing his commentary and corrections.

In his seventh point of criticism in the Assayer, Galileo takes Sarsi to task for deftly inserting "scherzi e le soavità poetiche," material he will associate directly with fables, at inappropriate moments in his texts. (VI, 233) The poetry that Galileo specifically targets is that of classical Latin auctores, who were frequently used as sources for observations of the natural world. Since poetic language is prone to hyperbole, allegorical interpretation, and what he considers to be other distortions of the literal truth, Galileo does not want to waste time arguing what may or may not be possible as it is stated in poetry. One famous example is how Babylonians could have ignited their slings by spinning them rapidly in circles, since no one taking part in the argument had actually seen the effect produced but only read such an account by the lexicographer Suidas. (VI, 340) Galileo wants the most current testimony as a basis for the argument. He complains that in the midst of reasoning about apparent deformities of the regular motion of a comet his mind ought to pacified by a non-philosophical phrase: "quietarsi e restar appagata d'un fioretto poetico."(VI, 234) In the same paragraph he reaffirms: "La natura non si diletta di poesia." He concludes by saying that Sarsi's inappropriate use of classical verse demonstrates either an ignorance of nature or of poetry, since he appears not to recognize a critical distinction: "alla poesia sono in maniera necessarie le favole e finzioni, che senza quelle non può essere; le quali bugie son poi tanto abborrite dalla natura, che non meno impossibil cosa è il ritrovarvene pur una, che il trovar tenebre nella luce." (VI, 234) Fables and fictions, the equivalent of poetry in Galileo's analysis, have no place in the discussion of the natural, physical world.

One of the books Galileo owned, Natale Conti's Mythologiae, provides a unique point of comparison with Galileo's position on the function of myth or fabulae in philosophy. The work was immensely popular in the late Renaissance, printed in at least twenty-seven editions, with the first in 1567. The fact that Galileo owned a copy is of little surprise. This mythography presents stories from the Greek and Roman traditions with com- 
mentary on their historical, physical, and ethical interpretations. The model for this genre was Boccaccio's De genealogia deorum gentilium, of which Galileo also owned a copy. Conti's preface speaks to the core of the traditional understanding of fabula in philosophy, describing the ancient Greeks who "found a secret mythological disguise" to safeguard their ideas from "ordinary men." 11 Conti supports the tenet that fable and philosophy were once inseparable: "what [the first philosophers] called philosophy was simply the ideas contained in those stories, once they were unwrapped and separated from their mythological coverings." $12 \mathrm{He}$ seeks to clarify the confusion generated by myth after the manner of philosophizing became straightforward and undisguised. Myth was interpreted by the subsequent generations as the "meaningless theology of fools, sometimes as old women's trifles, and at other times as the useless fabrications of lying poets." 13 Conti rejects the literal truth claims of the fable but emphasizes that "they explain the principles of honest living, ideas that we would otherwise reject were it not for the stories' charm." 14 Conti's sixteenth-century aesthetic is harmonious with the ways in which Galileo will employ fable as the vehicle for exempla of acceptable behaviour but reject fable's ability to describe the functions of the natural world in his philosophical treatises.

Galileo had many exempla traditions in his library - Greek, Roman, Italian, and even Indian collections. These were his models for narrating short stories and fables. The most obvious volumes are Aesop's Fables (in a 1541 Latin edition), Ovid's Metamorphoses in both Latin and Italian, Anton Francesco Doni's translation of Indian myth, the Moral filosofia (Venice, 1567), Giraldi Cinthio's Hecatommithi (Venice, 1566) and Sebastiano Erizzo's Sei giornate (Venice, 1567).15 There is little by way of

11 Mythologiae, 1:1-2.

12 Mythologiae, 2:888.

13 Conti, Mythologiae, 1:1-2. For connections with Galileo's interpretations of Scripture, see also Reeves, "Old Wives' Tales."

14 Mythologiae, 2:1-4.

15 Favaro, Libreria diGalileo. Galileo was also probably familiar with Boccaccio's Decameron, but given the turbulent history of the Decameron in sixteenth-century Italy, the inventories of family belongings that list the contents of Galileo's library likely suppressed its inclusion in any book list out of fear of prosecution for possessing banned books. With early publishing dates, the Ameto, Donne illustri and Genealogia degli dei (Venezia, 1547) could have belonged to Galileo's father (d. 1590). Nonetheless, the purchase of a 1594 edition of the Filocolo after his father's death suggests an interest in Boccaccian texts on Galileo's behalf. 
direct textual similarity that would suggest a literary lineage from Aesop, Ovid, or Doni to Galileo's tales. The same is true with the classical models for these brief demonstrative tales: Livy's $A b$ urbe condita and Maximus Valerius' Memorable Doings and Sayings. Valerius presents readers with a picture of public and private life of all social ranks in ancient Rome through collections of vignettes grouped by their common moral. The succinct style of many of Valerius' memorable deeds parallels the short tales that Galileo writes. The introduction of a protagonist, the description of the scene, and a summary of the action appear in one sentence that quickly and precisely directs the reader to the purpose of the tale. Even though Galileo did not borrow stories of Roman lawyers from Valerius or histories of criminals from Livy, these two classical collections do establish a tradition for the function of short stories, fictional or historical. In his preface to the $A b$ urbe condita Livy is direct about the critical selection he wishes his reader to take when encountering his history of the Roman people: "you should choose for yourself and your state what to imitate and what to avoid as abominable in its origin or as abominable in its outcome." 16 Livy requests an active participation from his readers to identify with one party or another. He also acknowledges that his work is a template for action, and encourages readers to imitate the best of what he has to offer. This call to imitate appropriate action as an intellectual will be essential to our reading of Galileo's own shortest stories, the exempla of the "abominable" characters that populate the Assayer. Galileo's rhetorical fables and these collections of short stories share similar narrative elements: fictional narration that is limited in scope and number of characters, with each element frequently disconnected in theme or characters in the collection. All are told to send a clear message about behavior to the reader.

Such is the case with the only positive example of behaviour shown by one of Galileo's fables, which is also the longest, and the one that structurally borders on the genre of the novella: the fable of sounds in the twen-

Cinthio's work was structured similarly to Boccaccio's with ten days of storytelling that included ten stories each, though Cinthio claims to be part of a different story-telling tradition. Cinthio was aiming for a more moral air than Boccaccio, as was Sebastiano Erizzo. Erizzo's Sei giornate is similar, with six days of telling six stories of each, again with a moralizing tone. In a climate of concern for the value of dialect, Tuscan and Latin, Boccaccio is particularly important. Given the centrality of Boccaccio to linguistic debate in the Cinquecento, his minimization in the library and in Galileo's writing reflect a distinct stylistic choice.

16 History of Rome, 3-4. 
ty-first section of the Assayer. This exemplum demonstrates the power of the fable to bring together the four relationships the author is negotiating in the text: tradition, reader, object of criticism, and program of inquiry. The story combines positively-framed intellectual action with mimicry of poetic language, proposing Galileo as the intellect capable of both proper means of inquiry and appropriate use of fictional texts for self-expression, where Sarsi has failed. In Galileo's notes on the Balance, this story begins as a single comment: "vi dico che ho la cicala in mano e non so come la canti; però posso ben dir della cometa che così lontana, etc." (VI, 137) From this analogy born of frustration springs a story that rejects the solitary life of the philosopher and suggests the dialogic nature of the new science. In the expanded version in the Assayer, Galileo begins the passage: "Parmi d'aver per lunghe esperienze osservato, tale esser la condizione umana intorno alle cose intellettuali, che quanto altri meno ne intende e ne sa, tanto più risolutamente voglia discorerne; e che, all'incontro, la moltitudine delle cose conosciute ed intese renda più lento ed irresoluto al sentenziare circa qualche novità."(VI, 279-80) Galileo takes on the voice of narrator and introduces an argument of seeming universal importance. His moral is far more specific than the standard "one must avoid pride" that an editor of a collection of exempla would use to label the story. He makes sure the reader is well-aware of the lesson to be learned from reading and removes all chances of a misinterpretation. He presents the frame and follows by introducing the main character, a scientific Everyman in search of truth who bears a striking resemblance to Galileo himself:

Nacque già in un luogo assai solitario un uomo dotato da natura d'uno ingegno perspicacissimo e d'una curiosità straordinaria; e per suo trastullo allevandosi diversi uccelli, gustava molto del lor canto, e con grandissima meraviglia andava osservando con che bell'artificio, colla stess'aria con la quale respiravano, ad arbitrio loro formavano canti diversi, e tutti soavissimi. (VI, 280)

Galileo has brought his reader to his oft-criticized realm of "favole e finzioni," an idyllic setting replete with relative superlatives, a grammatical choice he elsewhere derides in a fable about a negatively-cast sneaky nursemaid. The opening scene is that of the solitary life of contemplation so praised by the Humanists. ${ }^{17}$ That manner of philosophy and the subsequent style it proposed will be corrected by the content of the narrative.

This proto-modern scientist wanders from adventure to adventure in

17 Rigolot, "The Renaissance Crisis of Exemplarity," 559. 
search of all methods of producing sounds in the natural world, a parable of Galileo's new philosophy expressed with the narrative elements of popular fiction, not classical auctores. Andrea Battistini has called the Assayer and this story emblematic of a struttura picaresca of Galilean science, an observation that seems particularly apt after examining the favola dei suoni and knowing that Don Quixote was one of the books in Galileo's library. ${ }^{18}$ The first character that this fictitious natural scientist encounters is a shepherd, instantly recalling the literary genre of the pastoral, inspired by Sannazaro's Arcadia and popularized during this time period by Torquato Tasso's Aminta and Battista Guarini's Pastor fido, all three of which can be found in Galileo's library. Our fabling philosopher goes so far as to include a nearly-encyclopedic list of mechanisms for producing sound, but one that is invalidated by the conclusion of the story:

...trovossi più che mai rinvolto nell'ignoranza e nello stupore nel capitargli in mano una cicala, e che né per serrarle la bocca né per fermarle l'ali poteva né pur diminuire il suo altissimo stridore, né le vedeva muovere squamme né altra parte, e che finalmente, alzandole il casso del petto e vedendovi sotto alcune cartilagini dure ma sottili, e credendo che lo strepito derivasse dallo scuoter di quelle, si ridusse a romperle per farla chetare, e che tutto fu in vano, sin che, spingendo l'ago più a dentro, non le tolse, trafiggendola, colla voce la vita, sì che né anco poté accertarsi se il canto derivava da quelle. (VI, 281)

The vivisection of the cicada is an example of grotesque imagery typical of Giambattista Marino's seventeenth-century poetry. Galileo has rendered a tiny insect so significant that the favola is nearly two pages long, a tremendous amount of textual importance for an object that is superficially unrelated to astronomy. Expressed as it is in a settenario, the death of the cicada reads with the metricality and the lyricism of a death in battle taken from Galileo's favourite poem, Ariosto's Orlando furioso. ${ }^{19}$ The anaphor of né in the passage emphasizes the attention to linguistic style as well as mimics Galileo's apophatic method of reaching a justifiable hypothesis by negation of other possible solutions. Perhaps unsurprisingly, this prose blend of the

18 Galileo e $i$ Gesuiti, 3. See also Ezio Raimondi's analysis of this fable as picaresque in Scienza e letteratura,17-30.

19 For example, in the thirty-seventh canto of the Furioso, as Ariosto retells the story of Marganorre, Drusilla asks her dead husband to accept her revenge on his murderer with her dying breath until: "Finì il parlare insieme con la vita" (XXXVII.75.1). 
manner of philosophizing with contemporary poetry and parody was one of the most appreciated sections of the Assayer and is still anthologized today.

Yet, Galileo's fable of sounds does not find easy categorization with the volumes of his own library. It is a short story, a fable, and an exemplum. Through various poetic and prose allusions Galileo proposes a lesson on the human condition, using a variant of what he previously criticized as a "fioretto poetico" to indicate a truth about Sarsi, not the interpretation of comets. The piece stands alone in the text as the lengthiest fictional interlude, the only positively characterized fictional moment, and the densest passage of unspecified literary citations in the Assayer. The tale is a myth of philosophy that subverts its own claims of truth with its very conclusion. The final sentence of the favola explains the situation of Galileo, the scientist and author, when faced with scientific questions: "si ridusse a tanta diffidenza del suo sapere, che domandato come si generavano i suoni, generosamente rispondeva di sapere alcuni modi, ma che teneva per fermo potervene essere cento altri incogniti e inopinabili." (VI, 281) Knowledge will forever be a work in progress. Rather than something that can be etched in stone (or imprinted on paper), and unchanging, science to Galileo is like a book, or other work of the intellect that can be analyzed, supplemented, negated, revised, or placed in dialogue with other works. ${ }^{20}$ The mature expression of this dynamic conceptualization of philosophy appears in Galileo's later Dialogues on the Two Chief World Systems (1632) and the Discourses on the Two New Sciences (1638), where he represents the necessary second voice in a conversation. The protagonist of the fable of sounds is only able to reach his open-ended conclusion because he became social, because he encountered people and the world, wandering through some of the most popular community spaces of the literature of the period.

With this new kind of active inquiry comes the need for a new code of action, and this is where Galileo's use of fable is most pungent and vivacious. Galileo has a concern for revealing the mechanisms of duplicity in human nature in common with the authors of exempla in his library, be it Aesop, Valerius, Livy, Cinthio, or Doni. In his introduction to the translation of the Memorable Deeds and Sayings, Henry Walker says of contem-

20 One of the most frequently cited passages from the Assayer speaks to this point directly: "La filosofia è scritta in questo grandissimo libro che continuamente ci sta aperto innanzi agli occhi (io dico universo), ma non si può intendere se prima non s'impara a intender la lingua, e conoscer i caratteri ne' quali è scritto. Egli è scritto in lingua matematica, e i caratteri son triangoli, cerchi ed altre figure geometriche, senza i quali mezi è impossibile a intendere umanamente una parola; senza questi è un aggirarsi vanamente per un oscuro laberinto" (Opere VI, 232). 
porary readers that Valerius was, in a sense "showing them how to be imposters" of Republicans, that is, direct inheritors of a tradition that was not theirs by birth right. ${ }^{21}$ Anton Francesco Doni makes claims that his Moral filosofia is a mirror wherein readers will see the perils and deceptions of human existence. ${ }^{22}$ His audience will learn how to recognize this duplicity and will in turn be entertained for their efforts. Like Valerius and other authors, Doni suggests that his work offers universal intelligence to a general population. Galileo's goal is similarly to criticize such philosophical imposters and help his readers to identify phony intellectuals. Valerius teaches his readers to pose as Republicans, while Galileo attacks Sarsi and others for posing as legitimate inquisitive investigators. Ludovico Domenichi, in his Historia varia, the collection of witticisms, acknowledges that he has given examples that are more powerful than words. $\mathrm{He}$ describes the natural tendency of the human spirit when faced with exempla: "gli animi nostri per naturale istinto, vedendo uno atto di crudeltà, d'avaritia, o di altro vitio tale, subito haverlo per schifo." 23 From the novellas, to the classical histories, to the witticisms, each of these titles shares the possibility of having served as an inspiration to Galileo as he was composing the various narrative moments in the Assayer. In total there are several hundred examples of stories in Galileo's library that can be used for entertainment or education. They constitute a small arsenal with which to ridicule the faults of the ignorant, the critical, and the proud.

Given those conditions that trigger an exemplum or witticism, perhaps it is not surprising that the most common type of fable Galileo writes is the one that demonstrates how not to be a deceptive, ignorant, proud, or unjustly critical philosopher. The De Phaenomenis in orbe Lunae (1612) by the Jesuit, Aristotelian, philosopher, Giulio Cesare Lagalla, provides a typical, early example of Galileo's demonstrative fictional tale. Galileo writes in a margin next to a passage in which Lagalla concludes that the Earth is at the center of the universe by using a series of major and minor a priori premises:

non si accorgono questi signori Peripatetici di un grave errore che commettono, con danno notabile dell'istessa filosofia che professano; e questo è il produr quante più possono ragioni, tolte dalla medesima filosofia, per confermar una conclusione falsa; onde poi, chiaritasi la fal-

21 Maximus, Memorable Deeds and Sayings, xxi.

22 Le Novelle, 1-13.

23 Historia varia, 3. 
sità di questa sola, tutte quell'altre restano parimente false. E' fanno come quell'avvocato, che per difesa di un delinquente cercano di produr molti falsi testimonii: ma, accadendo poi che il principale resti convinto, non solo egli, ma tutti i testimonii restano infamati; talchè, per purgar l'infamia di un solo, ne infamano 10, ed anco quell'istesso e sè medesimo più gravemente ${ }^{24}$.

Tales of witty crooks who charm judges in order to grant their release and trickster lawyers who find clever ways to save their clients from execution are easy to find in the collections of short stories in Galileo's library, but the moral is quite different from the traditional exemplum. In those collections, a good laugh is had by all parties when the clever turn of phrase secures the release of the accused. In Galileo's version the crook is condemned, the lawyer dishonored, and the colluders are equally tarnished. Wit is never a quality of Galileo's guilty parties, though frequently it is the instrument of their judgment.

As seen from the margins of LaGalla's De phaenomenis and Galileo's response to Apelles in the Letters on Sunspots, these favole do not demonstrate observations of lunar mountains or solar flares but the faults of men in their various professions. Galileo's opponents are immoral lawyers or inept guardians of castles, characters easily recognizable to readers. The margins of Antonio Rocco's Esercitationi filosofiche, the Philosophical Exercises (1633) are no different. Here Galileo has called Rocco a number of insulting names and derides repeatedly his process of intellectual inquiry. In a moment of extended frustration, Galileo faces the problem of whether a line may be divided into an infinite number of segments only in theory or also in practice. He wonders subsequently whether or not that distinction has any relevance to the demonstration at hand. In a convincing visual argument easily put into practice, Galileo considers the line as a string that can be reshaped into polygons with varying numbers of sides, each side corresponding to a segment: each side of a square would be a fourth of the entire line, each side of an octagon, an eighth. Then Galileo makes the logical

24 Opere III, 341. Valerius Maximus gives us a similar, though more famous example: "Well, from his legal battles in the courts, Cicero won the highest honors and the most distinguished rank, but wasn't his testimony rejected in the very field of action of his eloquence? Cicero declared under oath that Publius Clodius had been visiting his house in Rome, whereas the only defense Clodius had against the charge of sacrilege was that he had not been in Cicero's house. Apparently the jury preferred clearing Clodius on the charge of sexual immorality over clearing Cicero of the disgrace of perjury" (Memorable Deeds and Sayings, 277-78). 
jump that both eliminates the need for a distinction between theory and practice and proves the validity of Galileo's own argument on infinite line segments: if the line were made into a circle, it would have an infinite number of sides, one for every point on its circumference, and accordingly could be divided into an infinite number of segments. With that said, Galileo promises his readers future admirable demonstrations:

la strada che si tiene comunemente nel voler comprendere i progressi della natura incammina così bene i filosofi suoi verso il termine desiderato, col bandire dalla lor mente gl' infiniti, gl'indivisibili, i vacui, come concetti vani e perniziosi ed esosi ad essa natura, come bene incamminerebbe il suo scolare quel pittore o quel fabro il quale gli desse per i primi principii il dar bando ai colori, ai pennelli, alle incudini, a i martelli, alle lime, come materie e strumenti inutili, anzi dannosi, a simili esercizii. (VII, 748)

How can one practice with proficiency, if all of the tools have been discarded? The answer is commonsensical. Through a series of fictional generic characters such as the wanderer, the artist, the lawyer, and others, Galileo begins to outline via analogy the tools and tactics of the new philosopher. These extended metaphors, vignettes, and abbreviated fables are much like the thought experiments that characterize Galileo's later works, which function via analogy to demonstrate laws of physics in objects that cannot simply be held in one's hand like a cicada. This kind of fabled rhetoric of method reaches its most mature elaboration in the marginal annotations of Sarsi's Astronomical Balance, which provide much of the material for Galileo's subsequent Assayer.

The fables or facezie become a map for intellectual processes. Accordingly the first instance of their use in Galileo's reading of the Balance in the Controversy on the Comets of 1618, is essentially a demonstration of improper ways of reading and equally improper ways of writing. At the bottom of the first pages of Galileo's copy of the Astronomical Balance, he has written:

Somiglia il Sarsi quello, che volendo comprare una pezza di raso o d'ermisino, la fa cavar fuor di bottega all'aria aperta, e quivi a falda a falda spiegandola, va con sottilissima diligenza ricercando se vi è una minima macchiolina, e un piccolissimo tagliuzzo; sopra 'l qual minimo defetto, se assorte velo ritrova, vuole screditar tutto 'l drappo, smaccarlo ed assai diminuirlo di prezzo, non mettendo in considerazione la gran diligenza, pazienza, dispendio di tempo e fatica è stata posta in fabbricare il resto tanto pulitamente: e quel che ha più del barbaro ed inumano, esclamerà 
d'una minima machhia o tagliuzzo di quell'istesso drappo, che allora, vestendosene, lo fa trinciare, anzi dilaniare, con 1000 stracci; e portandolo o in maschera o a qualche giuoco o spettacolo, sa che avanti sera deve essere tutto imbrodolato di fango e stracciato in pezzi. (VI, 160)

In an attempt to appear as an educated buyer, Sarsi pores over Galileo's fine textile, scouring page after page, line by line, for any error that would discredit the entire work. Galileo's approach when writing the Assayer is little different. Worse still, Sarsi removes the text(ile) from its context, the shop, in hopes of finding a different light that will show its defects. To make Sarsi's error as author more egregious, Galileo suggests that Sarsi is guilty of then using nearly perfect material to create a new patchwork text, much in the way that Galileo would later lament that the Padovan Peripatetics were capable of rearranging Aristotle to suit their purposes. (VII, 137-38) Galileo concludes the story with a final critique and a prediction. Sarsi is not buying the fine textile to wear while in serious employment. The cloth buyer is going to a masked ball, where he will hide his identity, just as Grassi hides behind Sarsi's name. Galileo adds that the cloth buyer could also be going to a game, where the sense of ludus is explicit, or to a spectacle, which emphasizes the superficiality of the entire commercial, but as it is implied, intellectual exercise. Galileo predicts that in the end, the new text will be torn to shreds, implying his own criticism as the agent.

The demonstrative tale of the cloth buyer does not refer specifically to any passage in Sarsi's text, but elements from this story do appear elsewhere in Galileo's corpus. The fabrics raso and ermisino are mentioned in line 193 of Galileo's scandalous Capitolo contro 'l portar del toga. ${ }^{25}$ Galileo places these fine textiles in humorous opposition to a clergyman's cape, as the professor tries to look smart while wrapped in expensive cloth. That element of excessive pretence and superficiality provokes the reader's derision of the professor, the cloth buyer, and by extension, Sarsi. Towards the end of his life, in the Lettera al Principe Leopoldo di Toscana of 1640, the matter is far more serious, and the metaphor more direct. Galileo is concerned that his perceived erroneous theories on the luminescence of the moon will mar the

25 Opere IX, 219. The value of fine clothing also appears in Lodovico Domenichi's Facetie, motti e burle in a story about the author Gherardo Spini: "essendogli ragionato di uno huomo ricco, vano, \& ignorante, come era copioso di vestimenti di grandissima valuta, argutamente rispose; che meglio assai sarebbe, che fusse degno di essere egli stimato, che di possedere cose degne d'essere stimate" (830). 
reputation of his colleague Fortunio Liceti's otherwise strong work:

non vorrei che anco questa nota, benchè piccola, macchiasse il suo, in tutto il resto, così puro e candido trattato: che nelli scritti miei, che poco di peregrino e di apprezzabile si contiene, poco di pregiudizio è l'aggiugnere a tante altre mie fallacie questa qui ancora; chè bene in un panno rozo e vile manco noiano la vista molte grandi ed oscure macchie, che in un drappo vago e per la moltitudine de' fiori riguardevole non farebbe una benchè minima. (VIII, 493)

The tone of this passage is more humble than in the criticism launched against Sarsi. Galileo claims his text is the stain, not the nearly-perfect philosophical fabric. He hopes that what he calls the flowers of Liceti's philosophy, no longer the "fioretti poetici" that he previously identified in Sarsi's work, will overshadow any mistake Galileo may have made. The point remains that these exercises of philosophy are still exercises of reading and writing, and Galileo has very high standards for both.

The criticism that follows in the marginalia of the Balance and the text of the Assayer spans from mere reproach for using an erroneous conclusion to support further argument, to using a deceitful style that mimics logical reasoning, while presenting what amounts to an intellectual sleight of hand. Galileo is always quick to point out to his readers the imposters and their strategy of deceit. Returning to the comet controversy, Sarsi questions the nature of the magnifying power of the telescope using a logic with which Galileo does not agree. Near the close of the first weighing in the Astronomical Balance Sarsi argues that Galileo's telescope brings "specters to the eyes and deludes the mind." 25 Sarsi's argument shifts focus quickly. $\mathrm{He}$ begins by recalling that the comet was judged to be further away than the Moon because it was magnified very little with the telescope, whereas the Moon is greatly magnified. He then moves to the common complaint that the telescope showed all objects, close or distant, as "bewitched and deformed." 26 Sarsi then explains that he abbreviated this argument in order to protect Galileo from calumny and quickly begins a discussion of the length of the telescope, saying that if the tube must be lengthened to look at objects close at hand, it should be shortened to magnify those distant. In the margins of Galileo's copy of the Astronomical Balance he has written a preliminary response:

25 Galilei, Controversy on the Comets, 80-81.

26 Galilei, Controversy on the Comets, 80. 
Messer Lottario, voi ci vorresti cambiar le carte in mano; e come la balia toglie il gioiello al bambino, e mostrandoli il cielo dice: "Ve' ve' gli angiolini," e supone in luogo della gemma una castagna, così vorresti voi con diverticoli gettarci la polvere negli occhi, e trattarci da insensati. Non è già questa dottrina Gesuitica. (VI, 128 n. 53)

By the time Galileo publishes the Assayer four years later, the sneaky nursemaid has been replaced by a catalogue of individuals. In the final version, after criticizing Sarsi for his absolute use of relative terms regarding distance, Galileo makes the reason for his fable obvious by using elements already present in the draft:

il Sarsi, senza assegnar termine o confine tra la vicinanza e lontananza, ha divisi gli oggetti visibili in lontani ed in vicini, errando in quel medesimo modo ch'errerebbe quel che dicesse: 'Le cose del mondo o son grandi o son piccole,' nella qual proposizione non è verità nè falsità, e così anco non è nel dire: 'Gli oggetti o son vicini o son lontani'; dalla quale indeterminazione nasce che le medesime cose si potranno chiamar vicinissime e lontanissime, grandissime, e piccolissime, e le più vicine lontane, e le più lontane vicine, e le più grandi piccole, e le più piccole grandi, e si potrà dire: 'Questa è una collinetta piccolissima,' e 'Questo è un grandissimo diamante;' quel corriero chiama brevissimo il viaggio da Roma a Napoli, mentre che quella gentildonna si duole che la chiesa è troppo lontana dalla casa sua. (VI, 263-64)

The nanny becomes three characters: the imaginary speaker of problematic relative phrases, the courier who does not complain about a quick trip from Rome to Naples, and the noblewoman who feels that the distance to her local church is a burden. The gem that is stolen from the baby becomes a diamond of unclear dimensions. More importantly, the moralizing tone of the story is significantly altered. What appeared in the first draft as deliberate trickery has been diffused into morally neutral ambiguity. The critique of the action remains, but the agency has been obscured.

Sarsi's hurried discussion of the relative distances to the Moon and the associated magnification power of the telescope earned significant critical commentary from Galileo. This is the only part of the Balance that received two marginal notes that take the form of fables or exempla. Immediately following the annotation about the thieving nursemaid, Galileo writes: "Vorrebbe il Sarsi ingannarci, come fa il pittore che, nel dipigner l'aurora, passa dal color bianco all'azurro con tal destrezza, che a guardare una striscia di larghezza di 4 dita per volta, par tutta del medesimo colore, ma gli estremi maxime distant. così a legger di 4 versi in 4 versi, etc." (VI, 128) 
Here, in the marginal annotation, the comparison between the verbal deception of Sarsi and the visual trick of the painter is clear. Similar to the diffused nursemaid, Sarsi the painter is reduced to a passing comment in the Assayer. Following up on the argument that Sarsi considers the moon both as a close and as a distant object, Galileo says in the Assayer. "è veramente un gran vantaggio aver la carta dipinta da tutte due le bande." (VI, 264) Galileo removes all action, and muffles all fault. By the time the critique of the Astronomical Balance moved from postilla to publication, he transformed the finger pointing in this passage into a gesture of general contempt for poor use of relative adjectives.

Galileo privately described the negative example of the philosopher as a group of weak defenders, a wasteful and falsely intelligent cloth buyer, a thieving nursemaid, the lawyer who is as guilty as his clients, and the artist who casts away the tools of his trade. Publicly, in print, these exempla either disappear or become diffused into a single man defending himself from an overwhelming and unidentified enemy, a woman who laments the distance to her church, or a speaker who uses relative terms. Yet, Galileo does not hold all of his punches in this move from margin to printed publication. In the section of criticism that follows the muted association of Sarsi with deception, Galileo points a finger at Sarsi's poor methodology:

Nè accade qui che il Sarsi la voglia star a sminuzzolare e rivedere a tutto rigor di geometria, perchè, quando ei l'avrà tirata e ridotta in atomi e presosi anco tutti i vantaggi, il guadagno suo non arriverà a quello di colui che con dilligenza s'andava informando per qual porta della città s'usciva per andar per la più breve in India. (VI, 266)

According to Galileo, Sarsi has lost the forest for the trees, just as the castellan from the first example of this rhetoric of exemplum would lose his castle by defending only one gate. Also in this section, in the margins of the Astronomical Balance, still only two pages after the painter and the nursemaid appear, Galileo writes the following note: "mi fa costui sovvenire di quel serpe, che, essendo stato tagliato in molti pezzi e morto, pur ancora va divincolando l'estremo pezzo della coda, con speranza di dare ad intendere a i viandanti, sè esser vivo e vittorioso.” (VI, 130) Galileo continues to attack Sarsi's slips between major and minor premises, causes and effects, and overall logical reasoning. He does so by referring to a natural phenomenon reported in Plutarch's Moralia. In Book XII of the Moralia, Gryllus responds to Odysseus's query about what virtue is to be found in beasts: 
Wild beasts, however, you will observe are guileless and artless in their struggles $[\ldots]$ it is their nature to flee subjection; with a stout heart they maintain an indomitable spirit to the very end. Nor are they conquered even when physically overpowered; they never give up in their hearts, even while perishing in the fray. In many cases, when beasts are dying, their valour withdraws together with the fighting spirit to some point where it is concentrated in one member and resists the slayer with convulsive movements and fierce anger, until, like a fire, it is completely extinguished and departs. ${ }^{27}$

Knowing that Galileo owned and annotated a copy of the Moralia adds force to the passage as a likely subtext for the note. In the Assayer the annotation gains force as a critique, rather than losing it as the nanny and the painter did: "Questo, Sig. Sarsi, è un ridursi al saltem, e un far come quella serpe che, lacerata e pesta, non le sendo rimasti più spiriti fuor che nell'estremità della coda, quella va pur tuttavia divincolando, per dare a credere a' viandanti d'essere ancora sana e gagliarda." (VI, 268) The message of duplicity is clear. The nanny and the painter may have been lost in the translation from marginalia to published volume, but the snake is still dying and still trying to convince others of its vigour.

As the criticism continues, the association of Sarsi with duplicity and outright illicit behaviour becomes more explicit, and the cast of exemplary bad characters expands. Nearing the end of the Balance, Sarsi claims that the entirety of a comet is illuminated, while Galileo argues that one is only able to see the part that is illuminated. He says there can be no certainty about the existence of a part of the comet that is not illuminated or does not reflect the light of the sun. Just as light is refracted through a glass or water, light from the sun, as it passes through the matter of a comet, would be equally distorted, leaving the true image of the comet unknown. In the Assayer he responds:

Questo del Sarsi è simil all'error di coloro che dicono che nessun delinquente deve mai confidarsi che il suo delitto sia per restare occulto, né s'accorgono dell'incompatibilità ch'è tra 'l restar occulto e l'essere scoperto, e che senz'altro chi volesse tener due registri, uno de' delitti che restano occulti, e l'altro di quelli che si manifestano, in quel degli occulti non ci verrebbe mai registrato e notato cosa veruna. (VI, 283)

Is Sarsi a criminal trying to hide a crime? Not exactly, but the pairing is suggestive. Galileo seeds the idea using this one sentence, a story that 
could likely have found its way into a collection of facezie. The only thing missing is the summary witticism, the wise remark from the author that makes explicit the humour of catching the foolish bookkeeper emptyhanded. The reader recognizes the vanity of such an enterprise, so the humour is not lost, merely transmuted into a sympathy with the author. With all of these exempla the presumed validity of Galileo's new philosophy carries out the function of both accusation and judgment.

The final example of "how not to philosophize" in the Assayer returns to the common themes of shoddy intellectual inquiry: duplicity and a desire to have the advantage at all costs. At the end of a lengthy examination of the reasons that the sun and moon appear larger to an observer when they are lower in the sky, the renewed sense of play is wedded to that of instruction. Galileo compares Sarsi to a poorly-skilled gambler who hopes to use an appearance of strength in order to force his opponent to retreat before he can realize the falsity of the claims being made:

voi arditamente le portiate avanti, imitando quel giocatore che, vedendosi d'aver a carte scoperte perduto l'invito, tenta con altro soprinvito maggiore di far credere all'avversario gran punto quello che piccolissimo vede egli stesso, onde, cacciato dal timore, ceda e se ne vada. E perchè io veggo che voi vi siete alquanto intrigato tra questi lumi primarii, refratti e reflessi ne' vapori o nell'occhio, comportate voi, come scolare, ch'io, come professore e maestro vecchio, vi sviluppi ancora un poco meglio. (VI, 356)

Galileo intimates that he has seen through both levels of deception at work in the Balance: the philosophical veils and the mask of the author. Returning once again to an image of ludus, reading, and rearranging similar to the cloth buyer, Galileo lets it be understood that whatever combination of cards, that is, textual passages, Sarsi recombines, and whatever expressions or rhetoric of confidence he may use to suggest that he has the winning hand, at the end of the game, when all cards are on the table, Sarsi will have lost the argument. The final seal on the exempla is the word of what Galileo calls himself in the story: the older, wise "maestro vecchio" who offers to teach his pupil the correct way to play. By extension, the reader should already know the lessons to be learned, albeit ex negativo.

According to this catalogue of fables, the poorly skilled philosopher is deceitful like a snake, lawyer, painter, nursemaid, and gambler; and he has lost sight of his purpose, as did the man buying cloth and the traveler to India. He is simply inept at his art, like the castellan, the pupil, or the craftsman who would discard the tools of his trade. These are characters 
pulled from collections of exempla, fables, and facezie. The protagonists in these tales, Galileo's and those in his library, are stunted in their experience of the human intellect or are somehow distracted from what Galileo sees as the purpose of intellectual investigation. Just as the Astrologo's competency to read the stars is called into question by the fact that he does not see the well into which he falls in Aesop's fable, Sarsi's accuracy of reading the natural world is undermined by what Galileo demonstrates as his inept, errant, and corrupt way of reading the books he holds in his hands. These fables, this "poesia" in Galileo's own terms, undercut Sarsi's method of investigation, which thereby calls into question his conclusions. By virtue of the form of the exempla, the reader sympathizes with Galileo's point of view. As such, these once-derided "fioretti poetici" become Galileo's agents to reveal a truth about the natural world through their legitimizing effect on the superior intellect of the new philosopher.

\section{UNIVERSITY OF KANSAS}

\section{Cited Works}

Accademia della Crusca. Vocabolario degli Accademici della Crusca. Venice: Appresso Giovanni Alberti, 1612.

Ariosto, Ludovico. Orlando furioso. Ed. Lanfranco Caretti. Turin: Einaudi, 1992.

Barillari, Sonia Maura, ed. Motti, arguzie, facezie [...] e altre forme semplici' dell'espressività popolare. Rome: Meltemi, 2000.

Battistini, Andrea. Galileo e i Gesuiti: miti letterari e retorica della scienza. Milan: Vita e Pensiero, 2000.

Bracciolini, Poggio. The Facetiae of Poggio and other Medieval Story-tellers. Trans. \& ed. Edward Storer. London: Routledge, 1928.

Bremond, Cl., J. Le Goff, and J.Cl. Schmitt. L'Exemplum. Turnhout: Brepols, 1982.

Cicero, Marcus Tullius. Cicero on Oratory and Orators. Trans. \& ed. J.S. Watson. Carbondale: Southern Illinois University Press, 1970.

Conti, Natale. Mythologiae. Trans. and ed. John Mulryan and Steven Brown. Tempe, AZ: ACMRS, 2006.

Delcorno, Carlo. Exemplum e letteratura tra Medioevo e Rinascimento. Bologna: il Mulino, 1989.

Domenichi, Ludovico. Historia varia. Venice: Gabriel Giolito de' Ferrari, 1564. Facetie, motti e burle di diversi signori et persone private raccolte per M. Lodovico Domenichi. Venice: Appresso G. Cornetti, 1588.

Doni, Anton Francesco. Le Novelle. Ed. Patrizia Pellizzari. Rome: Salerno Editrice, 2002.

Favaro, Antonio. "La libreria di Galileo Galilei, descritta e illustrata". Bullettino di bibliografia e storia delle scienze matematiche e fisiche 19 (1886): 219-93. 
Galilei, Galileo. Le opere di Galileo Galilei. Edizione nazionale sotto gli auspici di Sua Maestà il Re d'Italia. Eds. Antonio Favaro and Isidoro del Lungo. 20 vols. Florence: G. Barbèra, 1890-1909. Reprinted 1929-39 and 1964-66. Scritti letterari. Ed. Alberto Chiari. Florence: F. Le Monnier, 1970.

Galilei, Galileo, Horatio Grassi, Mario Guiducci and Johann Kepler. The Controversy on the Comets of 1618. Trans. Stillman Drake and C.D. O'Malley. Philadelphia: University of Pennsylvania Press, 1960.

Livy. Ab urbe condita. History of Rome. Trans. B.O. Foster. 14 vols. Cambridge, MA: Harvard University Press, 1976-77.

Maximus, Valerius. Memorable Deeds and Sayings. Trans and ed. Henry Walker. Indianapolis: Hackett, 2004.

Moss, Jean Dietz. Novelties in the Heavens. Rhetoric and Science in the Copernican Controversy. Chicago: University of Chicago Press, 1993.

Plutarch. Moralia. Trans. Harold Cherniss and William C. Helmbold. 15 vols. Cambridge, MA: Harvard University Press, 1957.

Raimondi, Ezio. Scienza e letteratura. Turin: Einaudi, 1978.

Reeves, Eileen. "Old Wives' Tales and the New World System: Gilbert, Galileo, and Kepler." Configurations 7.3 (1999): 301-54.

Rigolot, François. "The Renaissance Crisis of Exemplarity." Journal of the History of Ideas 59.4 (1998): 557-63.

Targa, M. Pietro. Cento e cinquanta favole tratte da diversi autori antichi. E ridotte in versi, e rime da M. Pietro Targa. Venice: appresso Giovanni Chrigero, 1569.

Valerio da Venezia. Prato fiorito di varij essempi. Venice: Francesco Groppo, 1695. 